\title{
The Effect of Problem Based Learning Model on Critical Thinking Ability Student Mathematics and Adversity Student Quotient on Students SMP Negeri 4 Lubukpakam
}

\author{
Saut Lamhot Sitanggang ${ }^{1}$, Edi Syahputra ${ }^{2}$, Anita Yus ${ }^{3}$ \\ ${ }^{1,2,3}$ Universitas Negeri Medan, Indonesia \\ ssaut97@gmail.com
}

\begin{abstract}
This study aims to determine the effect of the Problem-Based Learning model on students' mathematical critical thinking skills and Adversity Quotient. In addition, this study was also to see the interaction between learning and gender on students' mathematical critical thinking skills and Adversity Quotient. This research is a quasi-experimental research. The population in this study were all students at SMP N 4 LubukPakam for the 2020/2021 academic year, totaling 384 students. The research sample was 60 students, namely 30 students in class VII-1 and 30 students in class VII-2. The sample was selected by cluster random sampling. The instruments used were the mathematical critical thinking ability test and the Adversity Quotient attitude scale. The data obtained were analyzed using ANAVA in the Spss 20 program. The results showed that: 1) there was an effect of the Problem-Based Learning model on students' mathematical critical thinking skills with a significance value of $0.001<0.05 .2)$ there is an effect of the Problem-Based Learning model on students' Adversity Quotient with a significance value of $0.00<0.05 .3)$ there is no interaction between learning and gender on students' mathematical critical thinking skills with a significance value of $0.750>0.05 .4$ ) there is an interaction between learning and gender on students' Adversity Quotient with a significance value of $0.013<0.05$.
\end{abstract}

Keywords mathematical critical thinking ability; adversity quotient; gender; problembased learning

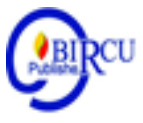

\section{Introduction}

Mathematics is the science that underlies the development of modern technological science, plays an important role in the development of other sciences and can also develop human thinking. In addition, mathematics is also a tool that helps, clarify and simplify a situation or situation that is abstract into concrete through language and mathematical ideas and generalizations, to facilitate problem solving.

In the attachment of the Minister of Education and Culture Number 58 of 2014 concerning the Junior High School curriculum, it is explained that one of the focuses of learning mathematics is to develop students' abilities in understanding mathematical concepts, explain the relationship between concepts, and use concepts or algorithms in a flexible, accurate, efficient and precise way in solving problems. . Based on the demands of the curriculum, the learning process developed in Indonesia really requires students to be actively involved in the process of teaching and learning activities so that their problem-solving abilities are more developed.

Based on the objectives of learning mathematics, it is assumed that problem solving ability is a general goal of learning mathematics even as the heart of mathematics. So, 
related to the aspect of problem-solving abilities in mathematics, a student is highly required to have a higher thinking ability. This is because thinking is a mental activity carried out by someone to help formulate or solve problems and make the right decisions according to what they want (Johnson, 2007). In addition, mathematical critical thinking skills are also very important in the learning process of mathematics. Because, mathematical critical thinking is the basis for a thought process to analyze arguments and generate ideas for each meaning to develop a logical mindset. The importance of mathematical critical thinking can also be seen from Susanto's (2013: 121) expression. Mathematical critical thinking is an activity to think about ideas or ideas related to a given concept or problem.

Some of the weaknesses of students in working on questions related to critical thinking as expressed by Saurino (2008) stated that many students were less critical, when students were given questions that contained critical thinking or solved problems students often missed and even did not do it. of student work on daily tests of integer material. In problems in the form of problem solving students can only write down what is known in the question, without including a plan for completion and completion. They tend to work on these problems only with the concepts taught by the teacher without using or connecting previously learned concepts. So when answering questions they always use the formulas and examples that were learned. This is evidenced by research conducted by Sholihah and Afriansyah (2017) which states that the factors causing students' difficulties in integer material are due to several reasons, namely a lack of understanding of concepts and positive exponents, lack of prior understanding of integer material. strong, lack of skills to use ideas in solving math problems related to integers, as well as classroom conditions that are less conducive to learning.

\section{Review of Literatures}

Every student has different difficulties in understanding the concept. To understand math problems, it requires endurance so that students are able to make difficulties as challenges and opportunities. The individual's ability to deal with this difficulty is called the Adversity Quotient. According to (Nurlaeli, et al; 2018) Adversity Quotient is an affective aspect that is considered necessary in studying mathematics. Based on the results of interviews with several students while making observations at SMP Negeri 4 Lubukpakam which stated that in the learning process activities the teacher in the classroom only explained the material, memorized formulas, recorded formulas and provided examples of questions then gave practice questions to students to work on. So that the learning carried out by the teacher in the classroom can be assumed to be conventional learning.

Gender is a factor that can affect critical thinking skills and Adversity Quotient (AQ). Gender is a characteristic of men and women based on socio-cultural dimensions as seen from their values and behavior. Krutetskii (1976) explains the differences between men and women in learning mathematics, namely that men are superior in reasoning, women are superior in accuracy, thoroughness, accuracy, and thinking accuracy.

The cause of low mathematical critical thinking skills and students' Adversity Quotient is the learning process. One of the mathematics lessons that provides opportunities to improve mathematical critical thinking skills and Adversity Quotient is through learning that is oriented to everyday problems. One of the lessons is ProblemBased Learning (PBL) which is a problem-based learning model that can help students 
understand the subject matter, and allow students to develop thinking skills. Problem based learning begins with students' understanding by providing real problems. Then students discuss to find solutions to the problems given. According to Arends (2008, p.57), states that there are several steps or learning syntax in the PBL model during discussion activities, namely, students analyze problems and get information and connect their ideas. In addition, it also teaches students to work well together and never give up and motivates each other in group discussions.

In the process of learning mathematics, critical thinking is a very important part. Mathematical critical thinking is a basic mathematical ability that is essential and needs to be possessed by students learning mathematics. According to Ennis (1991), which defines critical thinking as a process of using the ability to think rationally and reflectively which aims to make decisions about what to believe or do. In deciding what to believe and what to do, reliable information and an understanding of the topic or field of study are needed. A similar opinion was also expressed by Baron and Stemberg (1987) which states that critical thinking is a thought that is focused on deciding what to believe to do. This definition is a combination of five basic things in critical thinking, namely practical, reflective, reasonable, belief and action.

Adversity Quotient is a person's attitude in overcoming difficulties and processing these difficulties with their intelligence so that it becomes a challenge to solve them. Adversity Quotient (AQ) was first developed by Paul G. Stoltz. A consultant who is very well known in leadership topics in the world of work and skills-based education. Stolts categorizes individuals into three: quitter, camper and climber. From this experience, Stoltz then terms people who stop in the middle of the road before they finish as quitters, then those who feel satisfied are in a certain position as campers, while those who continue to want to achieve success are called climber.

Problem-based learning that comes from English Problem-Based Learning is a learning approach that starts with solving a problem, but to solve that problem students need new knowledge to be able to solve it. Problem-Based Learning is a learning concept that helps teachers create a learning environment that starts with important and relevant (related) problems for students, and allows students to gain more real learning experiences. According to Arends (2008: 42), problem based teaching (PBL) is an approach in which students work on authentic problems with the intention of compiling their own knowledge, developing inquiry and higher-order thinking skills, developing independence, and selfconfidence. In a classroom that applies PBL, students work in teams to solve real-world problems (Kurniasi and Sani, 2014: 75) and from the results of research conducted by Lubis, Asmin, and Syahputra (2017: 15) which show that the mathematical problemsolving abilities of students who receive the Problem-Based Learning (PBL) model are better than students who receive regular learning.

According to Pohan (2020) One of the mathematical skills that students must possess and achieve is problem solving. Problem solving is very close to mathematical characteristics. Problem solving is a process carried out to reach logical conclusions based on knowledge relating to facts and various relevant sources. Problem-based learning is a student-centered learning approach that organizes curriculum and learning in unstructured situations and provides realworld problems (Imelda, 2019). One of the teacher's main tasks is teaching. To be able to teach mathematics, a teacher must be able to prepare lesson plans so mathematics lessonscan be received by students. The learning process will run well if the teacher can design a great learning process, starting from planning the learning tools, learning activities in class, to evaluating them. (Wahyudi in Nasution, 2019). 


\section{Research Method}

\subsection{Research}

This study uses an experimental approach, to be precise a quasi experiment. This is because, as previously stated, this study aims to determine the critical thinking skills and Adversity Qoutient of the group of students who received Problem-Based Learning in the experimental class with the group of students who received conventional learning in the control class. The research design used was the Pre test Post test Control Group Design. This design consists of two groups that are randomly selected, then given a pretest to find out whether the initial state is there any difference between the experimental group and the control group (Sugiyono, 2015: 113). The pretest results served to assess the experimental group with the control group as not significantly different. The research designs or designs carried out are as follows:

Table 1. Research Design

\begin{tabular}{|c|c|c|}
\hline \multirow{2}{*}{ Gender $(\mathrm{B})$} & \multicolumn{2}{|c|}{ Learning Model $(\mathrm{A})$} \\
\cline { 2 - 3 } & $\begin{array}{c}\text { Problem-Based Learning } \\
\left(\mathrm{A}_{1}\right)\end{array}$ & $\begin{array}{c}\text { Conventional } \\
\left(\mathrm{A}_{2}\right)\end{array}$ \\
\hline Male $\left(\mathrm{B}_{1}\right)$ & $\mathrm{A}_{1} \mathrm{~B}_{1}$ & $\mathrm{~A}_{2} \mathrm{~B}_{1}$ \\
\hline Female $\left(\mathrm{B}_{2}\right)$ & $\mathrm{A}_{1} \mathrm{~B}_{2}$ & $\mathrm{~A}_{2} \mathrm{~B}_{2}$ \\
\hline
\end{tabular}

Information:
A
: Learning Model
B : Gender
$\mathrm{A}_{1} \quad$ : Learning Model Problem-Based Learning
$\mathrm{A}_{2} \quad$ : Conventional Learning Model
$\mathrm{B}_{1} \quad$ : Male
$\mathrm{B}_{2} \quad:$ Female
$\mathrm{A}_{1} \mathrm{~B}_{1} \quad$ : Male students' mathematical critical thinking skills learning using the Problem-Based Learning model.
$\mathrm{A}_{1} \mathrm{~B}_{2} \quad$ : Female students' mathematical critical thinking skills learning using the Problem-Based Learning model.

\subsection{Population and Sample Research}

The population in this study was all students of SMP Negeri 4 Lubukpakam, Lubukpakam District, Deli Serdang Regency in the academic year 2020/2021, totaling 384 students.

The research sample was selected by cluster random sampling. Two classes were chosen, namely class VII-1, VII-2 with 30 students each for class VII-1 and class VII-2 as many as 3 students.

\subsection{Research Instruments}

This study involved two instruments, namely test and non-test. This type of test instrument was given to determine the mathematical critical thinking skills in the form of a descriptive test consisting of 5 items tested on students on integer material. Meanwhile, the non-test instrument and form involved an Adversity Quotient questionnaire. The student's Adversity Quotient instrument used in this study consisted of 16 statement items, with 8 positive-directed statements and 8 negative-directed statements. 


\subsection{Data Analysis Technique}

This study uses inferential statistical analysis of two-way analysis of variance (ANOVA) or what is called Anava more than one path (Two Ways Analysis of Variance). This inferential statistical analysis is used to test the comparison as well as regression with the fulfillment of 2 requirements, namely the research sample is normally distributed and the research sample is homogeneous. Anava can be used to determine whether the mean values of two or more samples are significantly different or not. And to produce an $\mathrm{F}$ value that significantly indicates to the researcher that the sample under study comes from a different population (Arikunto, 2013). Anava is also one of the univariates that can be used to determine the effect and interaction of two factors with one dependent variable having the type of interval or ratio and several independent variables of the nominal or ordinal type. ANOVA used to determine the existence of an interaction is two-way ANOVA (Kadir, 2015).

Statistical hypothesis for students' mathematical critical thinking skills:

$\mathrm{H}_{0}$ : There is no significant effect between learning (PBL and conventional) on students' mathematical critical thinking skills.

$\mathrm{H}_{\mathrm{a}}$ : There is a significant influence between learning (PBL and conventional) on students' mathematical critical thinking skills.

Statistical hypothesis for students' Adversity Quotient:

$\mathrm{H}_{0}$ : There is no significant effect between learning (PBL and conventional) on students' Adversity Quotient)

$\mathrm{H}_{\mathrm{a}}$ : There is a significant influence between learning (PBL and conventional on students' Adversity Quotient.

Statistical hypothesis for the interaction between learning (PBL and Conventional) and Gender on students' mathematical critical thinking skills:

$\mathrm{H}_{0}$ : There is no interaction between learning (PBL and conventional) and gender on mathematical critical thinking skills)

$\mathrm{H}_{\mathrm{a}}$ : There is an interaction between learning (PBL and conventional) and gender on mathematical critical thinking skills.

Statistical hypothesis for the interaction between learning (PBL and Conventional) and Gender on students' Adversity Quotient:

$\mathrm{H}_{0}$ : There is no interaction between learning (PBL and conventional) and Gender on Adversity Quotient)

$\mathrm{H}_{\mathrm{a}}$ : There is an interaction between learning (PBL and conventional) and Gender on Adversity Quotient.

The test criterion is accept $\mathrm{H}_{0}$ if the significance value (sig) is greater than 0.05 and reject $\mathrm{H}_{0}$ if the significance value (sig) is less than 0.05 . 


\section{Discussion}

\subsection{Is There an Effect of the PBL Model on Mathematical Critical Thinking Skills?}

The first statistical hypothesis testing was carried out using two-way ANOVA. The results of statistical hypothesis testing using the two way ANOVA test assisted by SPSS 20.0 For windows software are presented in table 2 below:

Table 2. Hypothesis Test Results of Critical Thinking Ability

\begin{tabular}{|c|c|c|c|}
\hline $\mathbf{F}_{\text {count }}$ & $\mathbf{F}_{\text {table }}$ & Sig. & $\boldsymbol{\alpha}$ \\
\hline 12.106 & 4.01 & 0.001 & 0.05 \\
\hline
\end{tabular}

The results of the hypothesis test show that $\mathrm{F}$ count is 12.106 and sig. 0.001 in this case $\mathrm{F}$ table for $\mathrm{dFpembilang}=1$ and dFpenyebut $=56$ obtained by using interpolation, namely 4.01. It can be seen from table 2 that Fcount $(=12.106)>\mathrm{F}$ table $(=4.01)$ and sig. $(=0.001)<\alpha(=0.05)$, so there is sufficient evidence to make a decision that Ho is rejected and $\mathrm{Ha}$ is accepted. Thus, it means that there is an effect of the Problem-Based Learning model on students' mathematical critical thinking skills. In other words, the average mathematical critical thinking ability of students who use the Problem-Based Learning model is higher than the average mathematical critical thinking ability of students with conventional models.

\subsection{Is there an effect of the PBL model on the Adversity Quotient}

The second statistical hypothesis testing was carried out using two-way ANOVA. The results of testing the second statistical hypothesis using the two way ANOVA test assisted by SPSS 20.0 for windows software are presented in table 3 below:

Table 3. The Results of the Adversity Quotient Hypothesis Test

\begin{tabular}{|c|c|c|c|}
\hline $\mathbf{F}_{\text {count }}$ & $\mathbf{F}_{\text {table }}$ & Sig. & $\boldsymbol{\alpha}$ \\
\hline 172.355 & 4.01 & 0.00 & 0.05 \\
\hline
\end{tabular}

The results of the hypothesis test show that $\mathrm{F}$ count 172,355 and sig. 0.00 in this case the $\mathrm{F}$ table for $\mathrm{dFpembilang}=1$ and dFpenyebut $=56$ obtained by using interpolation, namely 4.01. It can be seen from table 3 that Fcount $(=172,355)>$ Ftable $(=4.01)$ and sig. $(=0.00)<\alpha(=0.05)$, so there is enough evidence to make a decision that Ho is rejected and $\mathrm{Ha}$ is accepted. Thus, it means that there is an influence of the Problem-Based Learning model on students' Adversity Quotient. In other words, the average Adversity Quotient of students who use the Problem-Based Learning model is better than the average Adversity Quotient of students who use conventional learning.

\subsection{Is There an Interaction between PBL Learning and Gender on Mathematical Critical Thinking Skills?}

The third statistical hypothesis testing was conducted to test whether there was an interaction between the Problem-Based Learning model and gender on students' mathematical critical thinking skills. In this case, gender is divided into two, namely men and women. The results of testing the third statistical hypothesis using the two way ANOVA test assisted by SPSS 20.0 For windows software are presented in table 4 below: 
Table 4. Hypothesis Test Results of the Interaction between Learning Models and Gender on Critical Thinking Ability

\begin{tabular}{|c|c|c|c|}
\hline $\mathbf{F}_{\text {count }}$ & $\mathbf{F}_{\text {table }}$ & Sig. & $\boldsymbol{\alpha}$ \\
\hline 0.103 & 4.01 & 0.750 & 0.05 \\
\hline
\end{tabular}

The results of the hypothesis test show that $F$ count is 0.103 and sig. 0.750 in this case the $\mathrm{F}$ table for $\mathrm{dFpembilang}=1$ and $\mathrm{dFpenyebut}=56$ obtained by using interpolation, namely 4.01. It can be seen from table 4 that Fcount $(=0.103)<$ Ftable $(=4.01)$ and sig. $(=$ $0.750)>\alpha(=0.05)$, so there is enough evidence to make a decision that Ho is accepted and $\mathrm{Ha}$ is rejected. Thus it can be stated that there is no interaction between models (PBL and conventional) and gender (male and female) on students' mathematical critical thinking skills. The absence of interaction can also be seen in Figure 1 below:

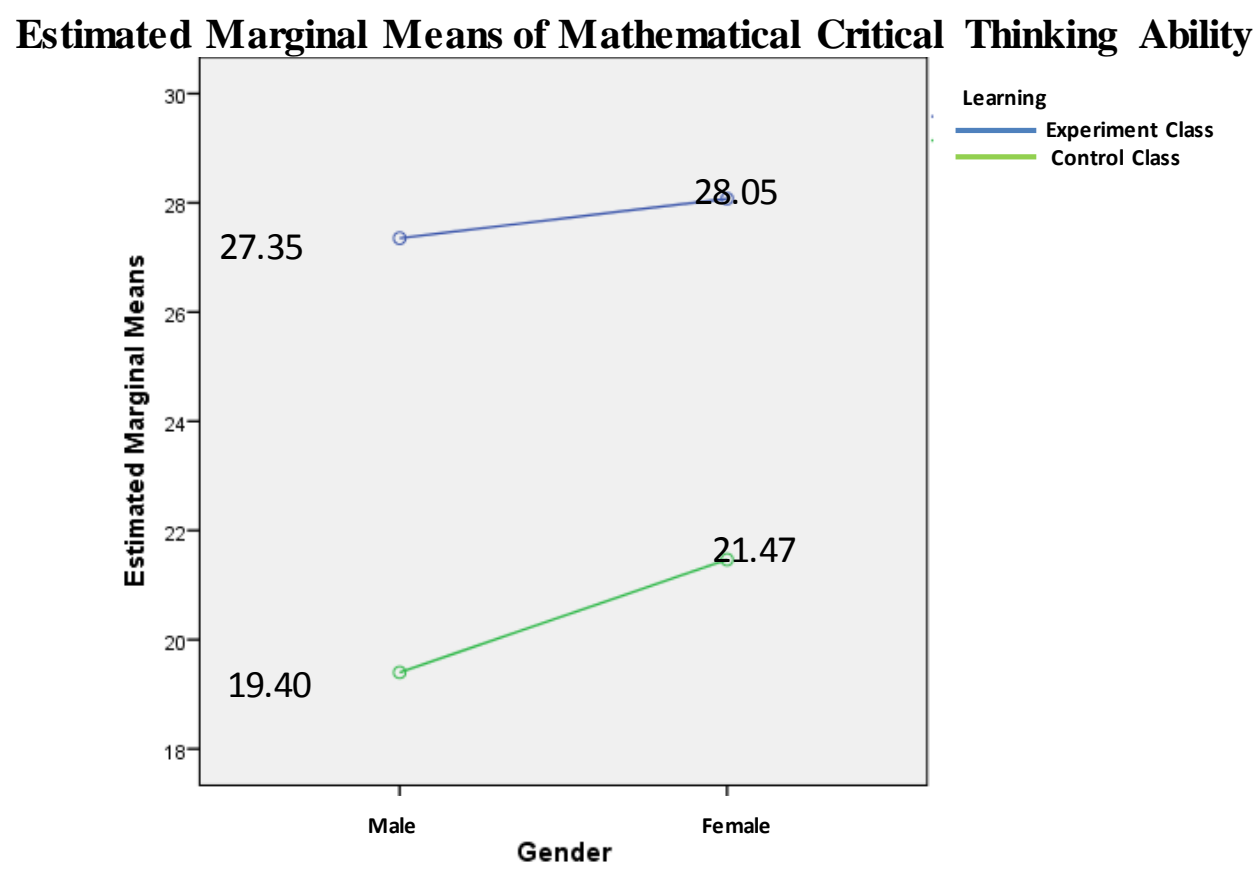

Figure 1. The Interaction Between Learning Models and Gender Against Students' Mathematical Thinking Ability

Figure 1 shows that the two lines do not meet or intersect at one point. This illustrates that there is no interaction between models (PBL and Conventional) and gender (male and female) on students' mathematical critical thinking skills. This means that critical thinking skills are influenced by the learning applied in the classroom.

\subsection{Is There an Interaction between PBL Learning and Gender on Adversity Quotient?}

The fourth statistical hypothesis testing was carried out to test whether there was an interaction between the Problem-Based Learning model and gender on students' Adversity Quotient In this case, gender is divided into two, namely men and women. The results of testing the fourth statistical hypothesis using the two way ANOVA test assisted by SPSS 20.0 For windows are presented in table 5 below: 
Table 5. Results of Interaction Hypothesis Test between Learning Model and Gender against Adversity Quotient

\begin{tabular}{|c|c|c|c|}
\hline $\mathbf{F}_{\text {count }}$ & $\mathbf{F}_{\text {table }}$ & Sig. & $\boldsymbol{\alpha}$ \\
\hline 6.530 & 4.01 & 0.013 & 0.05 \\
\hline
\end{tabular}

Hypothesis test results show that $F$ count 6,530 and sig. 0.013 in this case the $F$ table for dFpembilang $=1$ and $\mathrm{dFpenyebut}=56$ obtained by using interpolation, namely 4.01 . It can be seen from table 5 that Fcount $(=6.530)>$ Ftable $(=4.01)$ and sig. $(=0.013)<\alpha(=$ $0.05)$, so there is sufficient evidence to make a decision that Ho is rejected and $\mathrm{Ha}$ is accepted. Thus it can be stated that there is an interaction between the model (PBL and Conventional) and gender (Male and Female) on students' Adversity Quotient. The presence of interaction can also be seen in Figure 2 below:

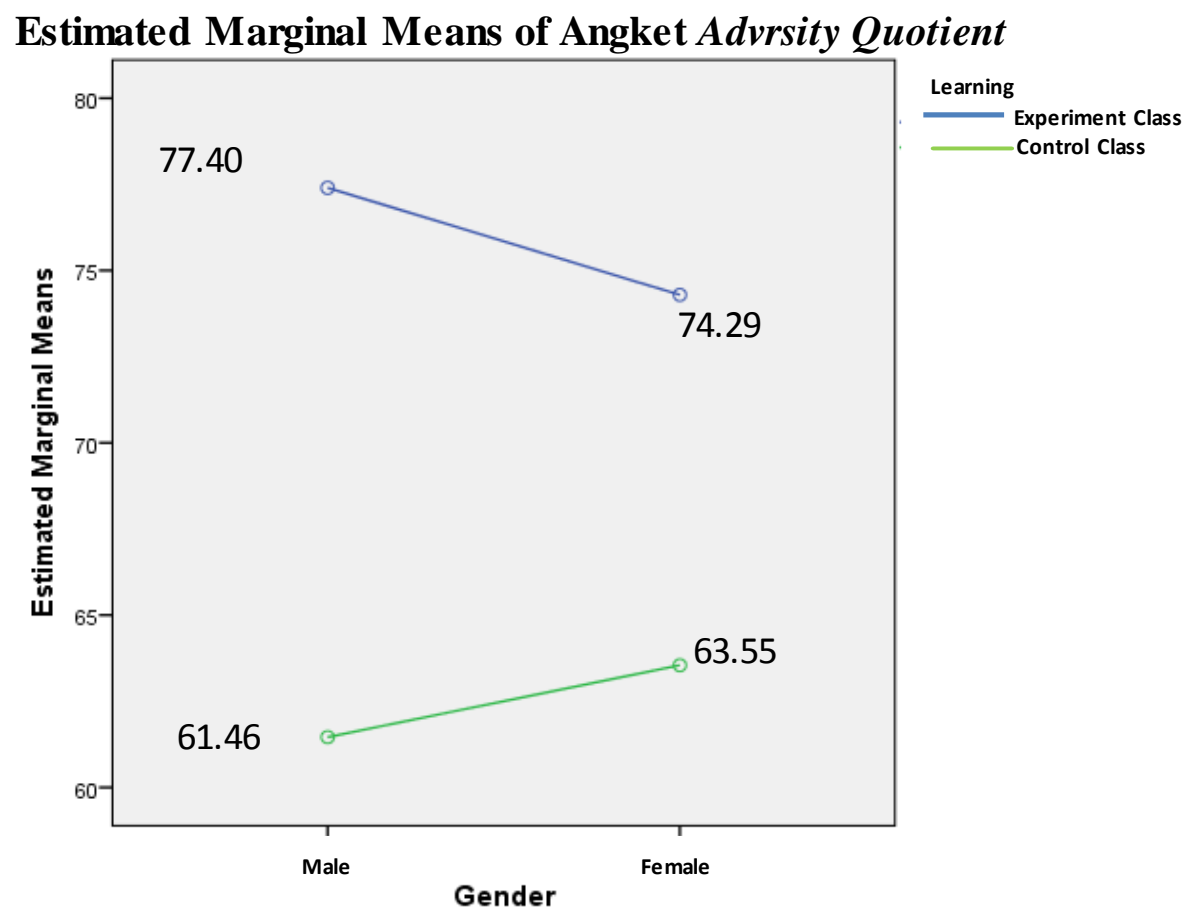

Figure 2. The Interaction between Learning Models and Gender against Student Adversity Quotient

Figure 2 shows that the two lines do not meet or intersect at one point. This illustrates that there is no interaction between the model (PBL and Conventional) and gender (male and female) on students' Adversity Quotient. This means that the Adversity Quotient is influenced by the learning applied in the classroom.

\section{Conclusion}

Based on the results of the analysis, findings, and discussion that have been stated in the previous chapter, the following conclusions are obtained: 1) there is an effect of the Problem-Based Learning model on the mathematical critical thinking skills of students of SMP Negeri 4 Lubukpakam. 2) there is an effect of the Problem-Based Learning model on the Adversity Quotient of SMP Negeri 4 Lubukpakam students. 3) there is no interaction between the Problem-Based Learning model and gender on the mathematical critical thinking skills of students of SMP Negeri 4 Lubukpakam. 4) there is an interaction between the ProblemBased Learning model and gender on the Adversity Quotient of SMP Negeri 4 Lubukpakam students. 


\section{References}

Arends, Richard.II. (2008). Learning to Teach. Penerjemah : Helly Prajitno \& Sri Mulyani. New York: McGraw Hill Company.

Arikunto, Suharsimi. (2013). Prosedur Penelitian Suatu Pendekatan Praktik. Jakarta: Rineka Cipta. Baron, J. B. Stemberg, R. J. (1987). Teaching Thinking Skill: Theory and Practise.New York: W. H. Freeman And Company.

Ennis, R.(1991). Critical Thinking. New Jersey: Prentice Hall.

Ennis, R.(2011). Critical Thinking. New Jersey: Prentice Hall.

Imelda, Anzelina, D. (2019). Students' Activities in Learning with Problem Based Learning Based Module to Enhance Students' HOTS on the Subject of Straight Line Equations. Budapest International Research and Critics in Linguistics and Education (BirLE) Journal Vol 2 (4): 552-559.

Johnson, Elaine B. PH.D. (2007). Contextual Teaching and Learning. Mizan Learning Center (MLC). Bandung.

Kadir. (2015). Statistika Terapan: Konsep, Contoh, dan Analisa Data dengan Program SPSS/Lisrel dalam Penelitian. Jakarta: PT. Rajagrafindo Persada.

Krutetskii, V. A. (1976). The Psychology of Mathematics Abilities in School Children. Chicago: The University of Chicago Press.

Kurniasi, I., BerliN, S. (2014). Sukses Mengimplementasikan Kurikulum 2013. Yogyakarta : Kata Pena

Lestari, K.E. dan Yudhanegara, M.R. (2015). Penelitian Pendidikan Matematika. Bandung: PT. Refika Aditama.

Nasution, Y.S., Syahputra, E., and Mulyono. (2020). The Development of Learning Instrument Using Problem Based Learning Model to Improve Critical Thinking of Junior High School Students.

Nurlaeli., Noornia. A., \& Dwi, E.W. (2018). Pengaruh Model Pembelajaran Problem Based Learning Terhadap Kemampuan Berpikir Kritis Matematis Siswa Ditinjau dari Adversity Quotient. Fibonacci. Vol 4 (2): 145-152.

Permendikbud No. 58 Tahun 2014 Lampiran III Tentang Kurikulum 2013.

Pohan, A.M., Asmin, and Menanti, A. (2020). The Effect of Problem Based Learning and Learning Motivation of Mathematical Problem Solving Skills of Class 5 Students at SDN 0407 Mondang. Budapest International Research and Critics in Linguistics and Education (BirLE) Journal Vol 3 (1): 531-539.

Saurino, D.R. (2008). Concept Journaling to Increase Critical Thinking Dispositions and Problem Solving Skills and Education. Dalam The Journal of Human ResourceandAdultLearning.Vol.4(1).[Online].Tersedia:https://pdfs.semanticscholar.org/7bc 3/5259dfa48fa459e7da90a17d27a933548052.pdf?_ga=2.120003393.89183788.

1580990516-632849474.1580990516.[06 Februari 2020].

Sholihah, S. Z., Afriansyah, E. A. (2017). Analisis Kesulitan Siswa Dalam Proses Pemecahan Masalah Geometri Berdasarkan Tahapan Berpikir Van Hiele. Jurnal Mosharafa. Vol. 6, No. 2, Pp 287-298.

Sugiyono. (2017). Metode Penelitian Kuantitatif dan $R \& D$. Bandung: Alfabeta.

Sugiyono. (2015). Metode Penelitian Kuantitatif dan $R \& D$. Bandung: Alfabeta.

Surya, E., Syahputra., and Juniati, N. (2018). Effect of Problem Based Learning Toward Mathematical Communication Ability an Self Regulated Learning. Journal of Education and Practice, (online), Vol.9, No.6, Pages, 14-23, (http://www.researchgate.net/publication/323509341

Susanto, A. (2013). Teori Belajar dan Pembelajaran di Sekolah Dasar. Jakarta: Prenada Media Group.

Stoltz, G. P. (2000). Adversity Quotient Mengubah Hambatan Menjadi Peluang. Jakarta: PT.Grasin. 